appreciated. The excellent secretarial assistance of Marylee Campion is acknowledged.

\section{REFERENCES}

1. Aguilera G, Parker DS, Catt KJ 1982 Characterization of somatostatin receptors in the rat adrenal glomerular zone. Endocrinology 111:1376

2. Aguilera G, Parker DS 1982 Pituitary somatostatin receptors. J Biol Chem 257:1134

3. Bhathena SJ, Louis J, Schechter GP, Redman RS, Wahl L, Recant L 1981 Identification of human mononuclear leukocytes bearing receptors for somatostatin and glucagon. Diabetes 30:127

4. Brown M, Rivier J, Vale W 1976 Biological activity of somatostatin and somatostatin analogs on inhibition of arginine-induced insulin and glucagon release in the rat. Endocrinology 98:336

5. Fitz-Patrick D, Patel YC 1981 Evidence for somatostatin precursors in human stomach, placenta, and amniotic fluid. J Clin Endocrinol Metab 53:372

6. Fitz-Patrick D, Patel YC 1979 Measurement, characterization, and source of somatostatin-like immunoreactivity in human amniotic fluid. J Clin Invest 64:739

7. Freychet P, Roth J, Neville DM Jr 1971 Monoiodoinsulin: demonstration of its biological activity and binding to fat cells and liver membranes. Biochem Biophys Res Commun 43:400

8. Guillemin R, Gerich J 1976 Somatostatin: physiologic and clinical significance. Annu Rev Med 27:379

9. Harrison LC, Billington T, East IJ, Nichols RJ, Clark S 1978 The effect of solubilization on the properties of the insulin receptor of human placental membranes. Endocrinology 102:1485

10. Haour F, Bertrand J 1974 Insulin receptors in the plasma membranes of human placenta. J Clin Endocrinol Metab 38:334

11. Holloway PW 1973 A simple procedure for removal of Triton X-100 from protein samples. Anal Biochem 53:304

12. Johansson C, Wisen O, Efendic S, Urnas-Wallenstein K 1982 Effect of somatostatin on gastrointestinal propagation and absorption of oral glucose in man. Digestion 22:126
13. Kumusaka T, Nishi N, Yaoi Y, Kido Y, Saito M, Okayasu I, Shimizu H, Hatatzeyama S, Swaro S, Kokobu K 1979 Demonstration of immunoreactive somatostatin-like substance in villi and decidua in early pregnancy. Am J Obstet Gynecol 134:39

14. Leitner WL, Rifkin RM, Maman A, Sussman KE 1979 Somatostatin binding to pituitary plasma membranes. Biochem Biophys Res Commun 87:919

15. Leitner JW, Rifkin RM, Maman A, Sussman KE 1980 The relationship between somatostatin binding and cyclic AMP-stimulated protein kinase inhibition. Metabolism 28:1065

16. Lowry OH, Rosebrough NJ, Farr AL, Randall RJ 1951 Protein measurement with the Folin phenol reagent. J Biol Chem 193:265

17. Macaron C, Kyncl M, Rutsky L, Halpern B, Brewer J 1978 Failure of somatostatin to affect human chorionic somatomammatropin and human chorionic gonadotropin secretion in vitro. J Clin Endocrinol Metab 47:1141

18. Marshall RN, Underwood LE, Voina SJ, Foushee DB, Van Wyk JJ 1974 Characterization of the insulin and somatomedin-C receptors in human placental cell membranes. J Clin Endocrinol Metab 39:283

19. Nishihira M, Yagihashi S 1978 Immunohistochemical demonstration of somatostatin-containing cells in the human placenta. J Exp Med 126:397

20. Reyl F, Silva C, Lewin MJM 1979 Somatostatin receptors on isolated gastric cells. In: Rosselin G, Framageot P, Banfils S (eds) Hormone Receptors in Digestion and Nutrition, pp 391-400. Elsevier/North-Holland, Amsterdam

21. Schonbrunn A, Tashjian AH Jr 1978 Characterization of functional receptors for somatostatin in rat pituitary cells in culture. J Biol Chem 253:6473

22. Schonbrunn A, Rorstad OP, Westendorf JM, Martin JB 1983 Somatostatin analogs: correlation between receptor binding affinity and biological potency in GH pituitary cells. Endocrinology 113:1559

23. Schusdziarra V, Zyznar E, Rouiller D 1980 Splanchnic somatostatin: a hormonal regulation of nutrient hemostasis. Science 207:530

24. Srikant CB, Patel YC 1981 Somatostatin receptors: identification and characterization in rat brain membranes. Proc Natl Acad Sci USA Neurobiology 78:3930

25. Sussman KE, Leitner JW, Rifkin RM 1978 Somatostatin selective inhibition of cyclic AMP stimulated protein kinase. Trans Assoc Am Physicians 91:129

26. Watkins WB, Yen SSC 1980 Somatostatin in cytotrophoblast of the immature human placenta: localization by immunoperoxidase cytochemistry. J Clin Endocrinol Metab 50:969

\title{
Determination and Characterization of Immunoreactive Trypsin in Amniotic Fluid from Normal and Cystic Fibrosis Fetuses
}

\author{
ANDERS BORGSTRÖM, TOMAS SVEGER, STIG KULLANDER, LARS SVANBERG, AND \\ PETER HÖSLI
}

Departments of Clinical Chemistry [A.B.], Pediatrics [T.S.], and Obstetrics [S.K., L.S.], University of Lund, Malmö General Hospital, Malmö, Sweden and Institut Pasteur, Department of Molecular Biology, Paris, France [P.H.]

\section{Summary}

High concentrations of immunoreactive trypsin (IRT) in the blood, and low concentrations of trypsin activity in fecal specimens have been found in newborn infants with cystic fibrosis (CF). The amniotic fluid concentrations of IRT and of IRT in complex with $\alpha_{1}$-antitrypsin $\left(\alpha_{1} \mathrm{AT}\right)$ were studied in 39 samples taken in about the 17th gestational week, and in 7 samples taken because the mothers had previously given birth to children with CF. The midtrimester samples contained trypsin in complex with

Received October 24, 1983; accepted March 13, 1984

Correspondence may be addressed to Anders Borgström, Department of Clinical Chemistry, University of Lund, Malmö, Sweden.

This research was supported by grants from the "Expressen" Prenatal Research Foundation and the E. T. Segerfalk's, A. Påhlssons and Svensson's Foundations for Medical Research. $\alpha_{1} \mathrm{AT}$ in a concentration of $30-200 \mu \mathrm{g} / \mathrm{liter}$, and small amounts of trypsinogen, 0-50 $\mu \mathrm{g} /$ liter. Three of four amniotic fluid samples from CF fetuses had very low concentrations of trypsin in complex with $\alpha_{1} \mathrm{AT}(<10 \mu \mathrm{g} /$ liter), and only small amounts of trypsinogen $(<10 \mu \mathrm{g} /$ liter $)$. Further prospective studies are needed to ascertain whether the determination of IRT in amniotic fluid may be of use in prenatal diagnosis of CF.

\section{Abbreviations}

$\alpha_{1} \mathrm{AT}, \alpha_{1}$-antitrypsin

CF, cystic fibrosis

g.w., gestational week

IRT, immunoreactive trypsin

RIA, radioimmunoassay 
Immunoreactive trypsin is one of several exocrine pancreatic proteins whose concentrations in the blood of infants with $\mathrm{CF}$ are increased $(3,7)$. These high concentrations may be due to an increased backflow of enzymes caused by partial obstruction of the pancreatic ducts. IRT activity is also decreased in dried fecal specimens obtained from CF neonates $(6,9)$. Trypsin is found in amniotic fluid as early as the 12th gestational week and in meconium in the 16th (14). IRT exists in two biologically significant forms, free trypsinogen and trypsin in complex with $\alpha_{1} \mathrm{AT}(1,2,5)$. These forms are found in serum and other body fluids containing protease inhibitors. An increased blood concentration of IRT in CF fetuses would theoretically lead to an increased urinary excretion of trypsinogen to the amniotic fluid. A decreased trypsin content of CF meconium would theoretically lead to a decreased trypsin- $\alpha_{1}$ AT complex concentration in amniotic fluid. Thus, assuming the $\mathrm{CF}$ fetal pancreatic glands to be affected in early intra-uterine life, as seems to be the case here in three of four cases, prenatal analysis and characterization of IRT from the amniotic fluid of normal and CF fetuses might provide useful diagnostic data.

Accordingly, the purpose of the present study was to determine and characterize IRT of amniotic fluid obtained at preterm deliveries and from normal and CF fetuses in the 16th-20th gestational week.

\section{MATERIALS AND METHODS}

Thirty-nine samples of amniotic fluid were obtained by amniocentesis between the 16th and 20th g.w. (determined by ultrasonic scanning); 32 of the samples were from pregnancies where there was increased risk of chromosome abnormality or neural tube defect, but of which the outcome was normal. Of seven pregnancies, where samples were taken because the mothers had already had children with $\mathrm{CF}$, three had normal outcomes (referred to as CF controls in the text), whereas four resulted in infants with cystic fibrosis. Nine samples were from preterm pregnancies, $32-36$ g.w. All samples were stored at $-20^{\circ} \mathrm{C}$ until analyzed (the $7 \mathrm{CF}$ risk samples for $0.5-2$ years, the remainder 1-4 months).

IRT was determined in duplicates with a conventional RIA (1). The normal IRT level in healthy individuals determined by this RIA is $25 \mu \mathrm{g} /$ liter. The IRT- $\alpha_{1} \mathrm{AT}$ complex was determined after gel filtration of the samples with a double antibody solid phase RIA (5). This RIA measures only IRT in complex with $\alpha_{1}$ AT (Fig. 2). The conventional assay, however, also measures trypsinogen and free trypsin. Furthermore, the presence of free $\alpha_{1}$ AT does not affect results when measuring IRT in complex with $\alpha_{1}$ AT.

The $\alpha_{1} \mathrm{AT}$ concentration was analyzed by electroimmunoassay (11). Antigen-antibody crossed immunoelectrophoresis was performed as previously described (13). Gel filtration of amniotic fluid was done on an AcA 54 column, $0.9 \times 16 \mathrm{~cm}$ (obtained from LKB, Bromma, Sweden).

\section{RESULTS}

In midtrimester (16-20 g.w.), the mean \pm SD IRT concentration in amniotic fluid from normal pregnancies was $28 \pm 25 \mu \mathrm{g} /$ liter (range, 3-100 $\mu \mathrm{g} /$ liter; $n=35$ ). The IRT concentration of preterm amniotic fluid (32-36 g.w.) was $11 \pm 14 \mu \mathrm{g} /$ liter (range, $1-18 \mu \mathrm{g} /$ liter; $n=9)$. Figure 1 shows the respective IRT concentrations.

The IRT was separated into two peaks by gel filtration; the first peak reacted and was measured by the specific trypsin- $\alpha_{1} \mathrm{AT}$ assay; the second corresponded to the molecular weight of trypsinogen and was measured by the IRT assay (Fig. 2). The

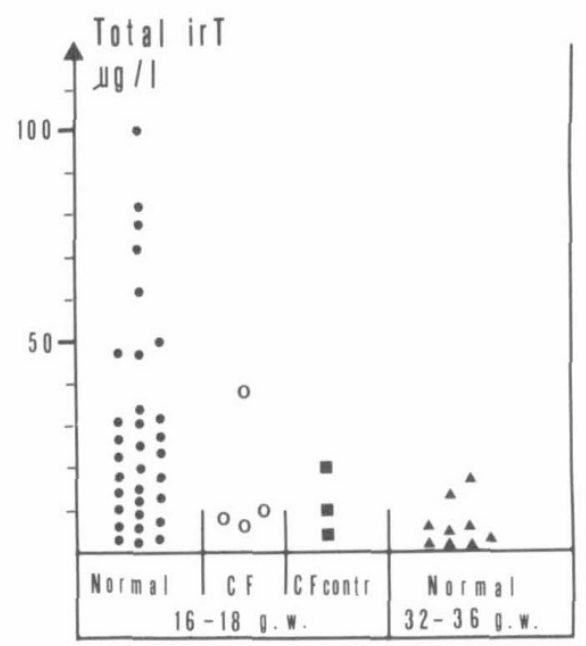

Fig. 1. The IRT concentrations of normal fetuses, around the 17 th

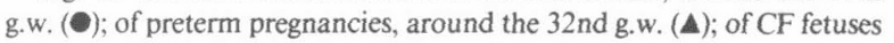

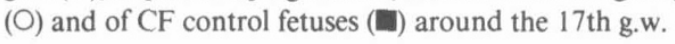

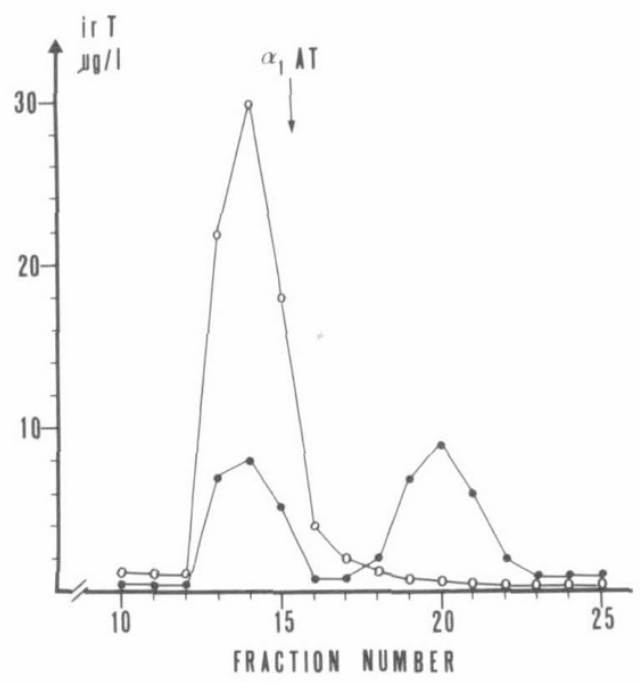

Fig. 2. Elution profile of IRT (-), and IRT in complex with $\alpha_{1}$ AT $(O)$, in an amniotic fluid sample obtained from a normal fetus around the 17 th g.w. AcA 54 column; sample volume, $0.5 \mathrm{ml}$; fraction volume, $0.5 \mathrm{ml}$. Arrow indicates the elution volume for free $\alpha_{1} \mathrm{AT}$.

midpregnancy samples contained trypsin in complex with $\alpha_{1} \mathrm{AT}$ in a concentration of $66 \pm 56 \mu \mathrm{g} /$ liter (range, $30-200 \mu \mathrm{g} / \mathrm{liter} ; n$ $=13$ ), and small amounts of trypsinogen, $16 \pm 15 \mu \mathrm{g} /$ liter (range, $0-50 \mu \mathrm{g} /$ liter; $n=13$ ). However, no trypsinogen was found in preterm samples, in which all the IRT was composed of the trypsin- $\alpha_{1}$ AT complex, $22 \pm 37 \mu \mathrm{g} /$ liter (range, 0-89 $\mu \mathrm{g} /$ liter; $n$ $=6$ ) (Fig. 3).

The amniotic fluid samples from three of four CF fetuses had very low concentrations of IRT (Fig. 1). Both trypsinogen and trypsin in complex with $\alpha_{1} \mathrm{AT}$ were found after gel filtration, although concentrations, particularly that of trypsin in complex with $\alpha_{1}$ AT, were low (Fig. 3).

The $\alpha_{1}$ AT concentration in amniotic fluid was $140 \pm 110 \mathrm{mg} /$ liter (range, 25-230 mg/liter; $n=39$ ). Crossed immunoelectrophoresis with antibodies specific for $\alpha_{1}$ AT gave only one immunoreactive peak, which is consistent with free $\alpha_{1} \mathrm{AT}$. When active bovine trypsin was added to the samples before the crossed immunoelectrophoresis, a peak appeared whose anionic migration rate was slower than that of free $\alpha_{1} \mathrm{AT}$, thus confirming that the bulk of the amniotic fluid $\alpha_{1} \mathrm{AT}$ was free and active. 


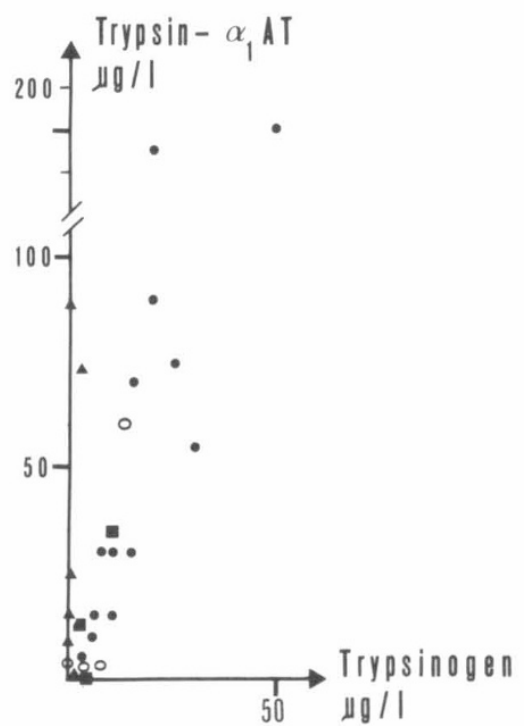

Fig. 3. The concentration of trypsin- $\alpha_{1} \mathrm{AT}$ complexes, and trypsinogen, determined after gel filtration of amniotic fluid samples obtained in the 17th g.w. from normal fetuses $(\bullet)$; from preterm pregnancies $(\boldsymbol{\Delta})$; from $\mathrm{CF}$ fetuses $(\mathrm{O})$ and $\mathrm{CF}$ control fetuses $(\square)$.

\section{DISCUSSION}

The IRT concentration of amniotic fluid found here is onetenth of that reported in a recent investigation (14), a discrepancy due to differences in purity of standard preparations. The method used in the report referred to gives a mean value in serum of healthy subjects which is 10 times that determined by our method $(1,8)$. Pocknee and Abramovich (14) suggested that the pancreatic enzymes reach the amniotic fluid via a physiological transfer of meconium in midpregnancy (D. R. Abramovich and E. S. Gray, unpublished ), a hypothesis confirmed by our gel filtration results which showed that the bulk of IRT in amniotic fluid consists of the trypsin- $\alpha_{1}$ AT complex. The active meconium trypsin is inactivated by $\alpha_{1} \mathrm{AT}$ which is available in large amounts in amniotic fluid. The discrepancy found between the results obtained by the RIA for total IRT, and those of the double antibody RIA for the trypsin- $\alpha_{1}$ AT complex, is explained by the fact that trypsin loses about $75 \%$ of its immunoreactivity after forming a complex with $\alpha_{1}$ AT (2). Accordingly, the trypsin- $\alpha_{1}$ AT RIA is preferable when the predominant form of IRT is trypsin$\alpha_{1}$ AT complexes as in amniotic fluid.

The wide variation of trypsin- $\alpha_{1}$ AT concentrations in normal amniotic fluid may be explained by an intermittent meconium passage, and wide variation of the amniotic fluid volume in the 17-18 g.w. (12). No free trypsin, or trypsin- $\alpha_{1}$ AT, passes from the mother to the amniotic fluid, since these complexes are never present in the normal circulation $(1,5)$. Three of four $\mathrm{CF}$ fetuses had very low trypsin- $\alpha_{1}$ AT concentrations in amniotic fluid. This fact may indicate a decreased trypsin meconium content in these $\mathrm{CF}$ fetuses.

Trypsinogen may be derived from both maternal and fetal sources. The ratio between amniotic fluid and maternal serum concentrations of proteins with a molecular weight slightly greater than that of trypsinogen (25,000 daltons), is quite variable, roughly $0.03-0.25(10)$. We found low concentrations of trypsinogen in preterm amniotic fluid, indicating a minor maternal contribution of trypsinogen. Accordingly, the amniotic fluid trypsinogen should mainly be of fetal origin and an increased concentration of trypsinogen in CF gestations was theoretically likely. Trypsinogen concentrations, however, were low even in CF amniotic fluids. Thus, other unknown factors probably influence the trypsinogen excretion in the amniotic fluid.

IRT is considered to be stable in serum samples stored at $-20^{\circ} \mathrm{C}$ even for several years (4). The effect of storage upon the IRT concentration of amniotic fluid has not yet been studied.

The fact, that three of four amniotic fluid IRT concentrations from CF fetuses were $<10 \mu \mathrm{g} /$ liter, compared with about one of four from normal pregnancies, suggests that the pancreas may be affected in midterm fetuses with CF. Further studies are necessary to determine the value of IRT analysis in the prenatal diagnosis of $\mathrm{CF}$.

\section{REFERENCES}

1. Borgström A, Ohlsson K 1978 Radioimmunological determination and characterization of cathodal trypsin-like immunoreactivity in normal human plasma. Scand J Clin Lab Invest 36:809

2. Borgström A, Ohlsson K 1978 Immunoreactive trypsin in serum and peritoneal fluid in acute pancreatitis. Hoppe-Seyler's Z Physiol Chem 359:677

3. Borgström A, Sveger T, Lindberg T, Kullander S, Svanberg L 1981 Immunoreactive trypsin, chymotrypsin, and pancreatic secretory trypsin inhibitor in cord blood from infants with cystic fibrosis. Acta Paediatr Scand 70:619

4. Borgström A, Sveger T, Lindberg T, Kollberg H, Larsson A 1982 Immunoreactive trypsin screening for cystic fibrosis. Acta Paediatr Scand 71:621

5. Borgström A, Ohlsson K 1984 A method for determination of immunoreactive trypsin in complex with $\alpha_{1}$-antitrypsin in human sera. Scand $\mathrm{J}$ Clin Lab Invest, in press

6. Crossley JR, Berryman CE, Elliott RB 1977 Cystic fibrosis screening in the newborn. Lancet 2:1093

7. Crossley JR, Elliott RB, Smith PA 1979 Dried blood spot screening for cystic fibrosis in the newborn. Lancet 1:472

8. Elias E, Wood T, Redshaw M 1977 Diagnostic importance of changes in circulating concentrations of immunoreactive trypsin. Lancet 2:66

9. Forrest DC, Wilcken B, Turner G 1981 Screening for cystic fibrosis by a stool trypsin method. Arch Dis Child 56:151

10. Johnson AM, Monansky I, Alper CA, Everett C, Greenspaw G 1974 Amniotic fluid proteins: maternal and fetal contribution. Pediatrics 14:588

11. Laurell CB 1972 Electroimmunoassay. Scand J Clin Lab Invest Suppl 124:1

12. Milunsky A 1979 Amniotic fluid. In: Milunsky A (ed) Genetic Disorders of the Fetus. Plenum Press, New York, p 48

13. Ohlsson K, Ganroth PO, Laurell CB 1971 In vivo interaction between trypsin and some plasma proteins in relation to intravenous infusion of trypsin in dog. Acta Chir Scand 137:113

14. Pocknee RC, Abramovich DR 1982 Origin and levels of trypsin in amniotic fluid throughout pregnancy. Br J Obstet Gynecol 89:142 